\title{
Pendidikan Multikulturalisme dan Budaya Bangsa
}

\author{
Hujair AH. Sanaky
}

Indonesia is plurality nation that consists of plurality in term of social, ethnicity, culture, religion, political party. The reality of Indonesia is called multi-cultural society. The concept of multi-cultural is so urgent to develop and internalize in the context of the above plurality values transformation process. Because those values afore-mentioned can become the fundamental basic for plurality society as Indonesia. The best and the strategic instrument to build, socialize this concept in order to produce conducive behaviour wisely either in social or in cultural is multi-cultural education, in particular Islamic education

Kata kunci: pendidkan, multikultural, bangsa, dan budaya

$\mathrm{M}$ erupakan kenyataan yang tak dapat ditolak, bahwa masyarakat dan bangsa Indonesia terdiri dari berbagai keragaman sosial, kelompok etnis, budaya, agama, aspirasi politik dan lain-lain, sehingga "masyarakat dan bangsa Indonesia secara sederhana dapat disebut sebagai masyarakat "multikultural". Di pihak lain, realitas "multikultural" tersebut berhadapan dengan kebutuhan mendesak untuk merekonstruksi kembali "kebudayaan nasional Indonesia" atau "budaya bangsa" yang dapat menjadi "integrating force" yang dapat mengikat seluruh keragaman etnis dan budaya tersebut'.(el-Ma'hady,2004)

Kesadaran tentang multikulturalisme sudah muncul sejak negara Republik Indonesia terbentuk dan digunakan oleh pendiri bangsa Indonesia untuk "mendesain kebudayaan bangsa Indonesia. Bagi bangsa Indonesia masa kini konsep multikulturalisme menjadi sebuah konsep baru dan asing" [Suparlan, 2002].Hal ini karena, kesadaran tentang konsep multikulturalisme yang dibentuk oleh pendiri bangsa ini tidak terwujud dan pada masa Orde Baru. Kesadaran tersebut dipendam atas nama kesatuan, persatuan dan stabilitas negara yang kemudian muncul paham monokulturalisme yang menjadi tekanan utama dan akhimya semuanya memaksakan pola yang berkarakteristik penyeragaman dalam berbagai aspek șistem sosial, politik dan budaya. Akhirnya, sampal saat ini, wawasan multikulturalisme bangsa Indonesia masih sangat rendah. Akibat dari rendahnya kesadaran dan wawasan multikulturalisme tersebut, menyebabkan berbagai kekisruhan etnis yang merebak di banyak tempat di wilayah Negara Kesatuan Republik Indonesia yang tentu merupakan bagian dari krisis multidimensi yang dihadapi negara dan bangsa Indonesia sejak pertengahan tahun 1997.

Perbedaan budaya, agama, aspirasi politik, kepentingan, visi dan misi, keya- 
kinan dan tradisi merupakan sebuah konduksi dalam hubungan interpersonal yang kadang-kadang juga menjadi perbedaan perilaku dalam memahami sesuatu. Misalnya, seseorang yang diajak bicara dalam mengungkapkan perhatiannya cukup dengan mengangguk-anggukan kepala. Namun ada sebagian orang dengan hanya mengedipkan kedua matanya untuk menyatakan persetujuan. Beberapa ahli psikologi menyatakan, bahwa budaya menunjukkan tingkat intelegensi dan kemajuan suatu masyarakat dan bangsa. Katakan saja, gerakan lemah gemulai merupakan ciri utama masyarakat Bali dan kemampuannya untuk menguasai hal itu merupakan ciri dari tingkat intelegensinya.

Ketika Amerika Serikat ingin membentuk masyarakat baru pasca kemerdekaannya [4 Juli 1776] baru disadari, bahwa masyarakatnya terdiri dari berbagai ras dan asal negara yang berbeda. Dalam hal ini Amerika mencoba mencari terobosan baru dengan menempuh strategi menjadikan sekolah sebagai pusat sosialisasi dan pembudayaan nilai-nilai baru yang dicitacitakan. Melalui pendekatan inilah, dari SD sampai Perguruan Tinggi, Amerika Serikat berhasil membentuk bangsanya yang dalam perkembangannya melampaui masyarakat induknya, Eropa. Kaitannya dengan nilainilai kebudayaan yang perlu diwariskan dan dikembangkan melalui sistem pendidikan pada suatu masyarakat, maka Amerika Serikat memakai sistem demokrasi dalam pendidikan yang dipelopori oleh John Dewey. Intinya adalah toleransi tidak hanya diperuntukkan untuk kepentingan bersama akan tetapi, juga menghargai kepercayaan dan berinteraksi dengan anggota masyarakat [el-Ma'hady, 2004].

Konsep multikulturalisme tidaklah dapat disamakan dengan konsep keanekaragaman secara sukubangsa atau kebuda- yaan sukubangsa yang menjadi ciri masyarakat majemuk, karena multikulturalisme menekankan keanekaragaman kebudayaan dalam kesederajatan. Dengan demikian, multikulturalisme juga bukan hanya sebuah wacana tetapi sebuah ideologi yang harus diperjuangkan, karena dibutuhkan sebagai landasan bagi tegaknya demokrasi, HAM, dan kesejahteraan hidup masyarakatnya. Multikulturalisme bukan sebuah ideologi yang berdiri sendiri terpisah darj ideologi-ideologi lainnya, dan multikulturalisme membutuhkan seperangkat konsep-konsep yang merupakan bangunan konsep-konsep untuk dijadikan acuan bagi memahaminya dan menyebarluaskannya dalam kehidupan bermasyarakat [Suparlan, 2002].

Lebih lanjut Suparlan, menyatakan untuk memahami multikulturalisme diperlukan landasan pengetahuan berupa bangunan konsep-konsep yang relevan untuk mendukung keberadaan serta berfungsinya multikulturalisme dalam kehidupan masyarakat dan bangsa Indonesia.Bangunan konsep-konsep ini harus dikomunikasikan diantara para ahlj yang mempunyai perhatian ilmiah yang sama tentang multikultutralisme sehinga terdapat kesamaan pemahaman dan saling mendukung dalam memperjuangkan ideologi ini [Parsudi Suparlan, 2002]. Pendidikan sebagai sarana yang strategi untuk dapat mensosialisasikan dan memfungsikan konsep multikulturalisme dalam kehidupan masyarakat dan bangsa Indonesia.

Pertanyaannya, program pendidikan bagaimanakah yang relevan dengan kehidupan masyarakat dan bangsa dengan corak masyakarat majemuk ini ? Artinya, berbagai etnis, suku, agama ada di dalamnya. Masing-masing etnis dan suku tadi membawa kultur sendiri-sendiri dan 
keragaman etnis ini menjadikan masyarakat dan bangsa Indonesia yang multikultural. Oleh karenanya, pengakuan akan keragamaan etnis, suku dan budaya penting ditumbuhkan pada peserta didik, karena para pendiri bangsa ini sesungguhnya telah menempatkan ideologi multikultural sebagai dasar kehidupan bernegara dan berkebangsaan yaitu "Bhineka Tunggal lka. Maka, dalam ideologi multikultural perbedaan dalam kesederajatan diakui dan diagungkan, baik secara individual maupun secara kebudayaan. Sayangnya, penghargaan terhadap hal ini nyaris tidak pernah ditumbuhkembangkan terutama selama lebih dari 32 tahun masa pemerintahan Orde Baru dan selama kurun waktu itu, pendidikan selalu merupakan upaya atau berkarakteristik penyeragaman budaya.

Di masa lalu, sistem pendidikan nasiona] lebih bercerikan "keseragaman" yang berlandaskan pada budaya nasional yang berdiri di atas puncak-puncak kebudayaan daerah. Akibatnya, pendidikan diselenggarakan dengan aturan dalam konteks mayoritas yang bersaing dan berhadapan dengan minoritas dan dikelola oleh pemerintah untuk meluaskan atau mempersempit hal-hal yang substansi atau penting yang menyangkut dengan lingkup dan alokasi kewenangan. "Seiring dengan proses desentralisasi pendidikan yang dalam melibatkan peran serta masyarakat mengisyaratkan pengakuan terhadap manusia Indonesia dan masyarakat setempat [konsep otonomi daerah]. Ini berarti Undang-undang Sistem Pendidikan Nasional ditinjau dari perspektif filosofis harus beranjak dari suatu paradigma baru pendidikan menuju pada pengakuan terhadap aspirasi masyarakat dan individu. Dengan sendirinya, paradigma baru dalam Undang-undang Sistem Pendidikan Nasional harus mengacu pada pendidikan multi- kultural yaitu adanya kebudayaan beragam dalam suatu masyarakat yang tetap merupakan kesatuan" [Aisyah Amini, 2004:15-16] "Bhineka Tunggal Ika". Demikian juga kebutuhan pembelajaran individu berada dalam perbedaan realitas sosio-historis, sosio-ekonomis, sukubangsa, sosio-psikologis. Artinya, akan dihadirkan populasi sasaran beragam dalam konteks sistem pendidikan dan persekolahan [Serniawan, 2002].

Konsekuensinya sistem pendidikan kita masih harus dikelola dengan baik, konsisten, karena pendidikan merupakan. lapangan yang sentral dalam upaya menerjemahkan gagasan multikulturalisme, sehingga menjadi kenyataan dalam perilaku kehidupan masyarakat dan bangsa Indonesia. Agar gagasan multikultur terserap luas dan efektif, pendekatannya harus disebarkan, dikelola dan diwujudkan secara konsisten dalam pendidikan nasional. Sebab pendidikan multikulturalisme justru memberi dampak pada integrasi kebudayaan dan upaya mewujudkan integrasi nasional harus berpusat pada pengembangan integrasi kebudayaan secara nasional yang dalam hal ini pendidikan multikulturalisme memegang peranan yang kunci dan sangat strategis dalam upaya tersebut.

\section{Konsep Multikulturalisme}

Sebagaimana dikemukakan di awal, bahwa suatu kenyataan yang tidak dapat dipungkiri bahwa masyarakat dan negarabangsa Indonesia terdiri dari berbagai keragaman yaitu sejumlah besar kelompok etnis, budaya, agama, aspirasi politik dan lain-lain, sehingga "masyarakat dan negarabangsa Indonesia secara sederhana dapat disebut sebagai masyarakat "multikultural". Parsudi Suparlan, menyatakan, bahwa 
konsep multikulturalisme tidaklah dapat disamakan dengan konsep keanekaragaman secara sukubangsa atau kebudayaan sukubangsa yang menjadi ciri masyarakat majemuk, karena multiku!turalisme menekankan keanekaragaman kebudayaan dalam kesederajatan.

Konsep multikulturalisme juga mengulas berbagai permasalahan yang mendukung ideologi ini, yaitu politik dan demokrasi, keadilan dan penegakan hukum, kesempatan kerja dan usaha. Hak asasi manusia, hak budaya komuniti dan golongan mnoritas, prinsip-prinsip etika dan moral, tingkat serta mutu produktivitas serta berbagai konsep lainnya yang lebih relevan [Fay, 1996; Rex, 1985; dalam Suparlan, 2002]. Hal ini juga senada dengan apa yang dikemukakan Blum [dalam Atmadja, 2003], bahwa multikulturalisme meliputi sebuah pemahaman, penghargaan dan penilaian atas budaya seseorang dan sebuah penghormatan dan keingintahuan tentang budaya etnis orang lain. Artinya, meliputi sebuah penilaian terhadap kebudayaan-kebudayaan orang lain, bukan dalam arti menyetujui seluruh aspek dari kebudayaan-kebudayaan tersebut, melainkan mencoba melihat bagaimana kebudayaan tertentu dapat mengekspresikan nilai bagi anggota-anggotanya sendiri [Aisyah Amini, 2004:31-32].

Spradly [1997], "menitikberatkan multikultural pada proses transaksi pengetahuan dan pengalaman yang digunakan oleh anggota masyarakat untuk menginterpretasikan pandangan dunia mereka yang berbeda untuk menuju kearah kebutuhan kultur. Kata multikultural menjadi pengertian yang sangat luas [multi-discursive], tergantung dari konteks pendefinisian dan manfaat apa yang diharapkan dari pendefinisian tersebut, yang jelas dalam kebudayaan multikultural setiap individu mempunyai kemampuan berinteraksi dan bertransaksi meskipun latar belakang kultur masing-masing berbeda, karena sifat manusia antara lain, adalah [1] akomodatif, [2] asosiatif, [3] adaptabel, [4] fleksibel, dan [5] kemauan untuk saling berbagi".

Dari pandangan ini mengisyaratkan bahwa keragaman kultur mengandung unsur yang beragam dan sarat dengan nilai-nilai kearifan. Dalam kontek membangun tatanan masyarakat dan tatanan sosial yang kokoh, "nilai-nilai kearifan" yang dalam hal ini "kearifan sosial" dan "kearifan budaya" dapat dijadikan sebagai tali pengikat dalam upaya bersosialisasi dan berinteraksi antar individu atau kelompok sosial. Dengan "kearifan sosial" dan "kearifan budaya" dan berusaha mengeleminir perselihan dan konflik budaya yang kurang kondusif, tatanan kehidupan sosial masyarakat yang multikultural akan terwujud dalam perilaku saling menghomati, menghargai perbedaan dan menjaga satu dengan lainnya dalam prinsip-prinsip perbedaan tersebut. Selain itu, juga berusaha untuk mengeliminir atau menghilangkan tiga hal yang selalu mendasari terjadinya konflik, yaitu "[1] prasangka historis, [2] diskriminasi, dan [3] perasaan superioritas in-group feelingyang berlebihan dengan menganggap inferior pihak yang lain [out-group]" [Puwasito, 2003:147]. Apabila ketida hal ini tidak mampu dieliminir, maka konflik dan benturan antar kelompok karena perbedaan kepentingan, keinginan, visi, keyakinan dan tradisi, menjadi sesuatu legal dan lumrah, karena keringnya nilai-nilai kemanusiaan, keringnya nilai-nilai "kearifan sosial" dan "kearifan budaya" dalam relasi antar sesama manusia.

Konsep "multikulturalisme" yang diartikan para ahli sangat beragam antara satu dengan yang lainnya, tetapj pandangan mereka tentang "multikulturalisme" pada dasarnya adalah pandangan terhadap dunia 
yang kemudian diterjemahkan dalam berbagai kebijakan kebudayaan yang menekankan tentang penerimaan terhadap "realitas keragaman", "pluralitas" dan "multicultura!" yang terdapat dalam kehidupan masyarakat. Oleh karenanya, multikulturalisme dipahami sebagai pandangan dunia yang kemudian diwujudkan dalam "politics of recognition". Dengan pengertian yang beragam dan kecenderungan perkembangan konsep dan praktek multikulturalisme, Parekh [1997:183-185, dalam Azyumardi], membedakan lima macam bentuk multikulturalisme dan tentu saja kelima bentuk multikulturalisme itu tidak "kedap air" [watertight], tetapi sebaliknya dapat saja tumpang tindih satu dengan lainnya dalam segi-segi tertentu, yaitu :

Pertama, "multikulturalisme isolasionis" yang mengacu kepada masyarakat di mana berbagai kelompok kultural menjalankan hidup secara otonom dan terlibat dalam interaksi yang hanya minimal satu sama lain. Contoh-contoh kelompok ini adalah seperti masyarakat yang ada pada sistem "millet" di Turki Usmani atau masyarakat Amish di AS. Kelompok ini menerima keragaman, tetapi pada saat yang sama berusaha mempertahankan budaya mereka secara terpisah dari masyarakat lain umumnya.

Kedua, "multikulturalisme akomodatif", yakni masyarakat plural yang memiliki kultur dominan, yang membuat penyesuaian dan akomodasi-akomodasi tertentu bagi kebutuhan kultural kaum minoritas. Masyarakat multikultural akomodatif merumuskan dan menerapkan undangundang, hukum dan ketentuan-ketentuan yang sensitif secara kultural, dan memberikan kebebasan kepada kaum minoritas untuk mempertahankan dan mengembangkan kebudayaan mereka; sebaliknya kaum minoritas tidak menantang kultur dominan. Multikulturalisme akomodatif ini dapat ditemukan di Inggris, Perancis, dan beberapa negara Eropa lain.

Ketiga, "multikulturalisme otonomis", yakni masyarakat plural di mana kelompokkelompok kultural utama berusaha mewujudkan kesetaraan [equality] dengan budaya dominan dan menginginkan kehidupan otonom dalam kerangka politik yang secara kolektif bisa diterima. Concern pokok kelompok-kelompok kultural terakhir ini adalah untukmempertahankan cara hidup mereka, yang memiliki hak yang sama dengan kelompok dominan; mereka menantang kelompok kultural dominan dan berusaha menciptakan suatu masyarakat di mana semua kelompok bisa eksis sebagai mitra sejajar. Jenis multikulturalisme didukung misalnya oleh kelompok Quebecois di Kanada, dan kelompok-kelompok Muslim imigran di Eropa, yang menuntut untuk bisa menerapkan syari ah, mendidik anak-anak mereka pada sekolah Islam, dan sebagainya.

Keempat, "multikulturalisme kritikal" atau "interaktif", yakni masyarakat plural di mana kelompok-kelompok kultural tidak terlalu concern dengan kehidupan kultural otonom; tetapi lebih menuntut penciptaan kultur kolektif yang mencerminkan dan menegaskan perspektif-perspektif distingtif mereka. Kelompok budaya dominan tentu saja cenderung menolak tuntutan ini, dan bahkan berusaha secara paksa untuk menerapkan budaya dominan mereka dengan mengorbankan budaya kelompokkelompok minoritas,karena itulah kelompokkelompok minoritas menantang kelompok kultur dominan, baik secara intelektual maupun politis, dengan tujuan menciptakan iklim yang kondusif bagi penciptaan secara bersama-sama sebuah kultur kolektif baru yang egaliter secara genuine. Jenis multikulturalisme, sebagai contoh, 


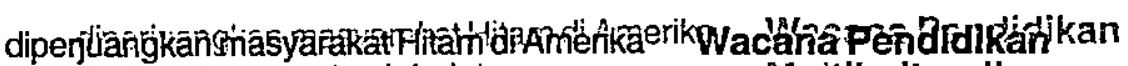

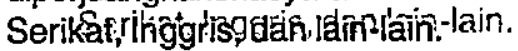

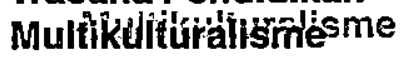

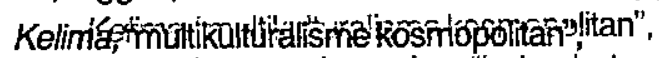

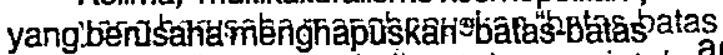

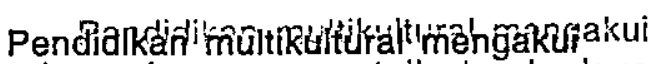

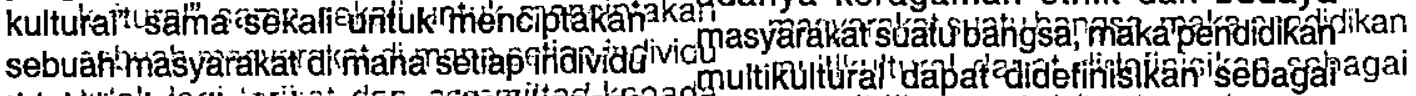

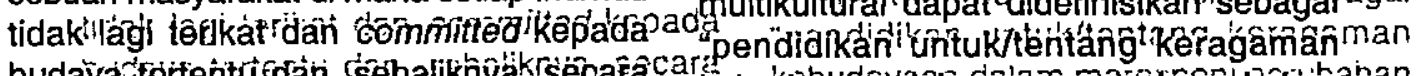

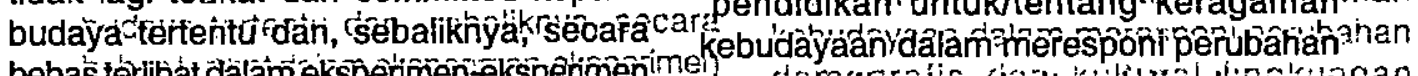

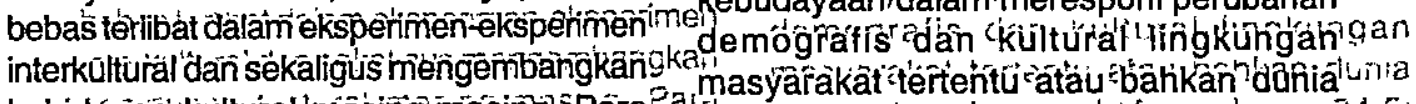

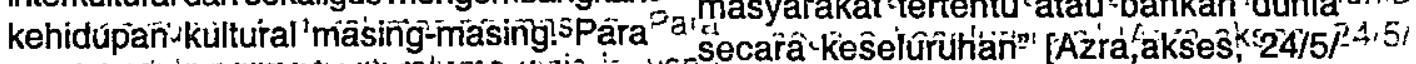

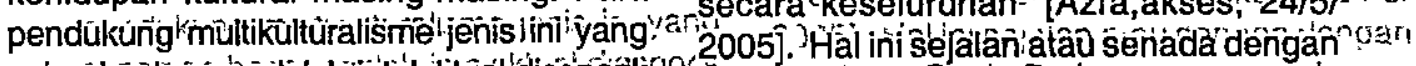

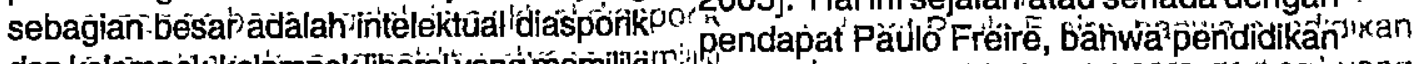

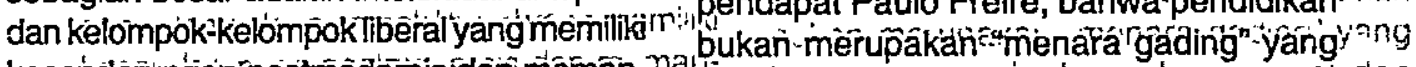

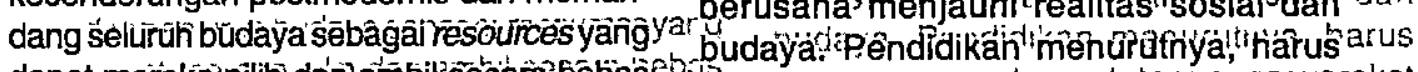

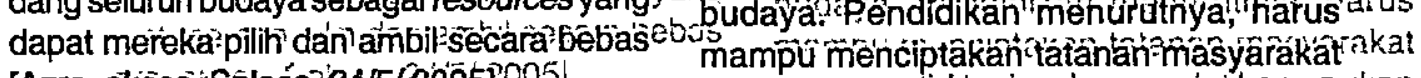
[Azra, akses, Selaśa;24/5/2005]:005|.

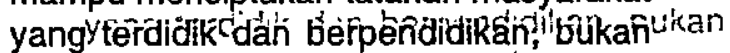

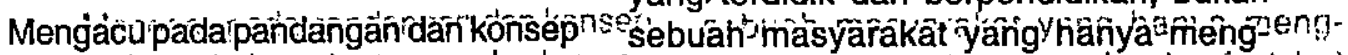

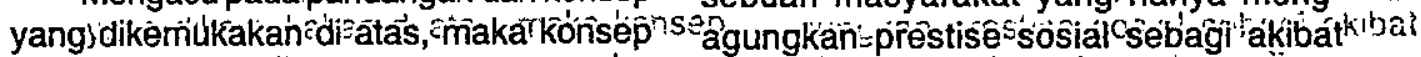

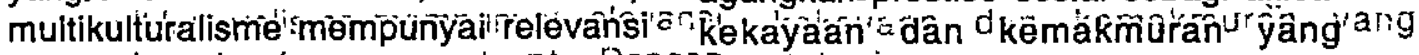

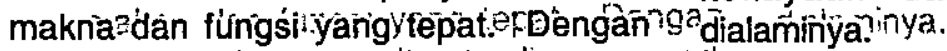

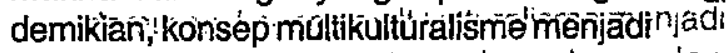

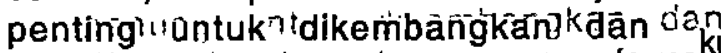

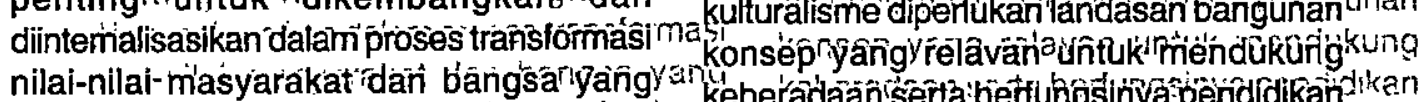

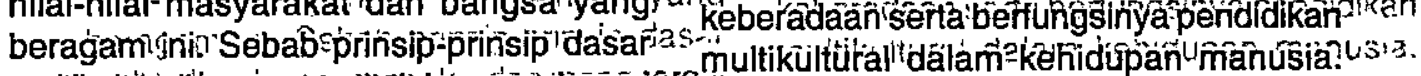

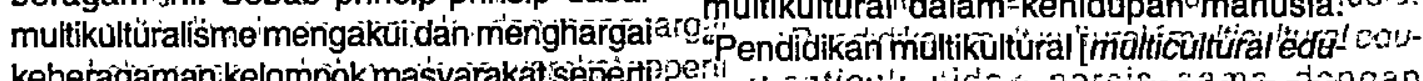

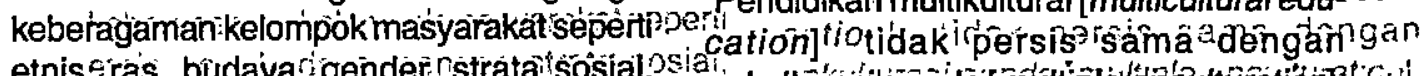
etnis, ras, budayafi gender, nstratait sósial, siali

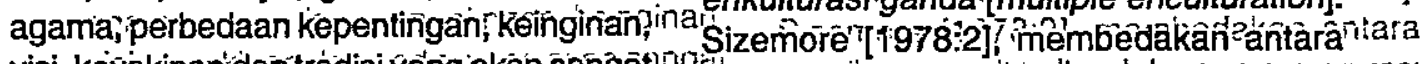

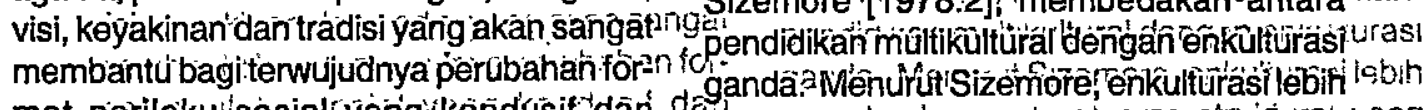

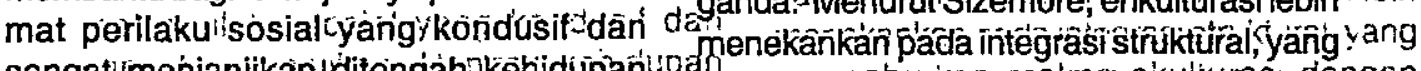

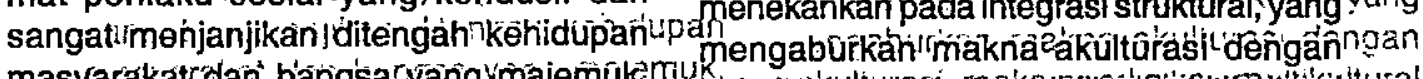

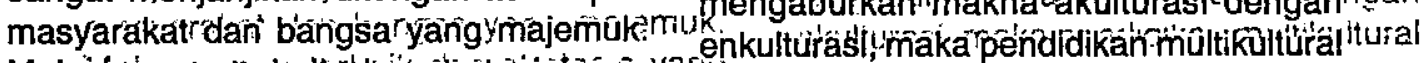

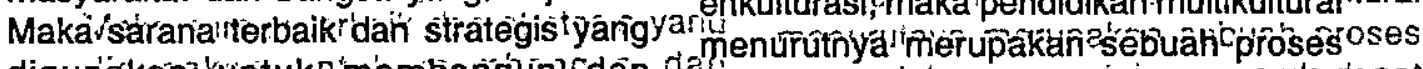

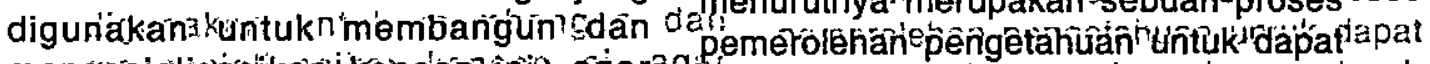

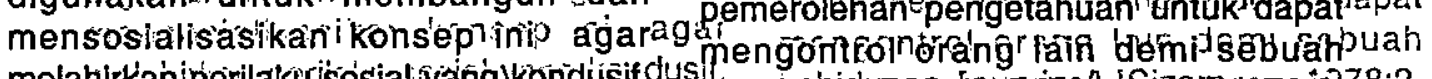

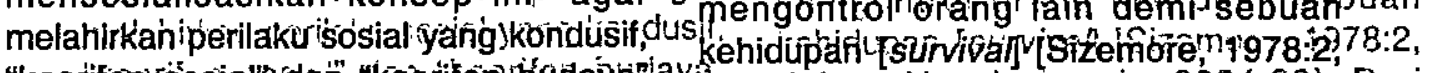

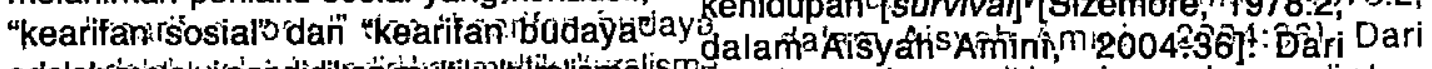

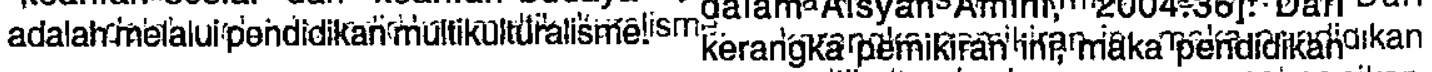

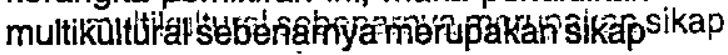


"peduli" dan mau mengerti [difference], atau "politics of recognition", politik pengakuan terhadap orang-orang dari kelompok minoritas [Cf Taylor et al 1994, dalam Azra, 2002].

Ânderson dan Cusher [dalam Hasan: 2001], menyatakan bahwa multikultural adalahi pendidikan keragaman kebudayaan. Konsep ini, mengandung unsur yang lebih luas, meskipun demikian posisi kebudayaan masih sama yakni mencakup keragaman kebudayaan menjadi sesuatu yang dipelajari sebagai objek studi. Dengan kata lain, keragaman kebudayaan menjadi materi pelajaran yang harus diperhatikan, khususnya bagi rencana pengembangan kurikulum. Azra menyatakan, bahwa pendidikan multikultural sebagai pengganti dari pendidikan interkultural, diharapkan dapat menumbuhkan sikap peduli dan mau mengerti atau adanya politik pengakuan terhadap kebudayaan kelompok manusia seperti; toleransi, perbedaan etno-kultural dan agama, diskriminasi, HAM, demokrasi dan pluralitas, kemanusiaan universal serta subyek-subyek lain yang relevan [Azra, akses, 24/5/2005].

Secara operasional, pendidikan multikultural pada dasamya merupakan program pendidikan yang menyediakan sumber belajar yang jamak bagi pebelajar [multiple learning environments] dan yang sesuai dengan kebutuhan akademik maupun sosial peserta didik [Aisyah Amini,2004:37]. Pendidikan multikuitural [multicuitural education] merupakan respon terhadap perkembangan keragaman populasi sekolah, sebagaimana tuntutan persamaan hak bagi setiap kelompok. Dalam dimensi lain, pendidikan multikultural merupakan pengembangan kurikulum dan aktivitas pendidikan untuk memasuki berbagai pandangan, sejarah, prestasi dan perhatian terhadap orang-orang non Eropa [Hilliard,
1991-1992]. Secara luas pendidikan multikultural itu mencakup seluruh siswa tanpa membedakan kelompok-kelompoknya seperti gender, etnic, ras, budaya, strata sosial dan agama. Selanjutnya James Banks [1994] menjelaskan, bahwa pendidikan multikultural memiliki empat dimensi yang saling berkaitan antara dengan lainnya, yaitu : [1] Content integration, mengintegrasikan berbagai budaya dan kelompok untuk mengilustrasikan konsep mendasar, generalisasi dan teori dalam mata pelajaran atau disiplin ilmu. [2] The Knowledge Construction Process, membawa siswa untuk memahami implikasi "budaya" ke dalam sebuah mata pelajaran [disiplin]. [3] An Equity Paedagogy, menyesuaikan "metode pengajaran" dengan "cara belajar siswa" dalam rangka memfasilitasi prestasi akademik siswa yang beragam baik dari segi ras, budaya ataupun sosial, dan [4] Prejudice Reduction, mengidentifikasi karakteristik ras siswa dan menentukan metode pengajaran mereka [e]Ma'hady, 2004].

Tilaar, menyatakan pendidikan mulkikultural merupakan fenomena yang relatif baru di dalam dunia pendidikañ. Sebeiun Perang Dunia II boleh dikatakan pendiailíain multikultural belum dikenal.Malah pendidikan dijadikan sebagai alat politik untuk melanggengkan kekuasaan yang memicnopoli sistem pendidikan untuk kelompoks tertentu. Dengan kata lain pendidikan multikultural merupakan gejala baru di dajan pergaulan umat manusia yang mendambakan persamaan hak, termasuk hak untur. mendapatkan pendidikan yang sama untuk semua orang, "Education for All" [H.A.R. Tilaar,2004: 123].Pendidikan multikultural sebenarnya berawal dari berkembangnya gagasan dan kesadaran tentang "interkulturalisme" seusai Perang Dunia II. Kemunculan gagasan dan kesadaran 
"interkulturalisme"ini selain terkait dengan perkembangan politik internasional menyangkut HAM, kemerdekaan dari kolonialisme, dan diskriminasi rasial, dan lain-lain, juga karena meningkatnya pluralitas di negara-negara Barat sendiri sebagai akibat dari peningkatan migrasi dari negara-negara yang baru merdeka ke Amerika dan Eropa" [Tilaar (2002:495].

Pada dasawarsa 1940-an dan 1950-an di Amerika Serikat berkembang konsep pendidikan "inter-kultural" dan "interkelompok" [inter-cultural and inter-group education]. Maka, pada hakikatnya pendidikan interkultural merupakan crosscultural education untuk mengembangkan nilai-nilai universal yang dapat diterima berbagai kelompok masyarakat berbeda [cf.La Belle 1994:21-27, dalam Azra]. "Pada tahap pertama, pendidikan interkultural ditujukan untuk mengubah tingkah laku individu untuk tidak meremehkan apalagi melecehkan budaya orang atau kelompok lain, khususnya dari kalangan minoritas. Selain itu, juga ditujukan untuk tumbuhnya toleransi dalam diri individu terhadap berbagai perbedaan rasial, etnis, agama, dan lain-lain" [Azra, akses,24/5/2005]. Lebih lanjut Azra, menyatakan "harus diakui, bahwa pada prakteknya pendidikan interkultural lebih terpusat pada individu daripada masyarakat" [Azra,akses,24/5/ 2005]. Lagi pula, konflik dan benturan antar kelompok dalam skala luas yang terjadi bukan dalam skala individu, melainkan pada tingkat kelompok dan masyarakat yang mengusung unsur-unsur kepentingan dan politik, sehingga hal ini benar-benar mengganggu hubungan atau relasi antar sesama di antara kelompok,warga masyarakat, bangsa dan negara. Nilai-nilai kemanusiaan mulai kering dan kaku dalam relasi antar sesama manusia, perbedaan visi, kepentingan, keyakinan, tradisi, budaya dan politik seakan-akan selalu menjadi sumber konflik dan telah menjadi suatu yang lumrah dan legal pada perilaku kehidupan mianusia datam era saat ini. Dari kondisi ini, Azra [akses,24/5/2005], menyatakan bahwa "pendidikan interkultural dipandang kurang berhasil dalam mengatasi konfjik antar golongan dan masyarakat dan dari kenyataan ini pula menurutnya pada gilirannya dan sudah saatnya kita harus mendorong munculnya gagasan tentang pendidikan multikultural", karena dalam program pendidikan multikultural, tidak lagi diarahkan semata-mata kepada kelompok rasial, agama dan kultural dominan atau mainstream saja.

Sebagajmana dikemukakan Tilaar, bahwa dalam program pendidikan multikultural, fokus tidak lagi diarahkan semata-mata kepada kelompok rasial, agama dan kultural dominan atau mainstream. Kerena, fokus seperti ini pernah menjadi tekanan pada pendidikan interkulturalyang menekankan peningkatan pemahaman dan toleransi individu-individu yang berasal dari kelompok minoritas terhadap budaya mainstreamyang dominan, yang pada akhirnya dapat membuat orangorang dari kelompok minoritas terintegrasi ke dalam masyarakat mainstream [Tilaar, 2002:498]. Dengan "pendidikan interkultural seperti ini pada akhirnya memunculkan tidak hanya sikap tidak peduli [indifference] terhadap nilai-nilai budaya minoritas, tetapi bahkan cenderung melestarikan prasangkaprasangka sosial dan kultural yang rasis dan diskriminatif [Azra,akses,24/5/2005]. Dan dari kerangka inilah, "pendidikan multikultural sebenarnya merupakan sikap "peduli" dan mau mengerti [difference], atau "politics of recognition"politik pengakuan terhadap orang-orang dari kelompok minoritas [Cf Taylor et al 1994, dalam Azra, 2002]. 
Dalam konteks itu, pendidikan mujtikultural melihat masyarakat secara lebih luas. Berdasarkan pandangan dasar bahwa sikap "indifference" dan "non-recognition" berakar tidak hanya dari ketimpangan struktural rasial, paradigma pendidikan multikultural mencakup subyek-subyek mengenai ketidakadilan, kemiskinan, penindasan dan keterbelakangan kelompokkelompok minoritas dalam berbagai bidang; sosial, budaya, ekonomi, pendidikan, dan lain-lain. Paradigma seperti ini pada gilirannya mendorong tumbuhnya kajiankajian tentang "ethnic studies", untuk kemudian menemukan tempatnya di dalam kurikulum pendidikan sejak dari tingkat dasar sampai ke tingkat pendidikan tinggi. Tujuan inti dari pembahasan tentang semua subyek ini adalah untuk mencapai pemberdayaan [empowermenf] bagi kelompokkelompok minoritas dan disadvantaged [Azra, akses,24/5/2005].

Istilah "pendidikan multikultural" [multicuitural education] dapat digunakan baik pada tingkat deskriptif dan normatif, yang menggambarkan isu-isu dan masalahmasalah pendidikan berkaitan dengan masyarakat multikultural. Lebih jauh ia juga mencakup pengertian tentang pertimbangan terhadap kebijakan-kebijakan dan strategistrategi bagi pendidikan bagi peserta didik di dalam masyarakat multjkultural. Dalam konteks deskriptif dan normatif ini, kurikulum pendidikan multikultural mestilah mencakup subjek-subjek seperti; toleransi; tema-tema tentang perbedaan ethno-kultural, dan agama; bahaya diskriminasi; penyelesaian konflik dan mediasi; HAM; demokrasi dan pluralitas; kemanusiaan universal, dan subjek-subjek lain yang relevan [Azra, akses,24/5/2005 dan el-Ma'hady, 2004].

Berdasarkan pandangan yang dikemukakan di atas, maka perumusan dan implementasi pendidikan multikultural di Indone- sia, masih memerlukan pembahasan serius dan khusus. Hal ini bukan hanya karena menyangkut masalah isi pendidikan multikultural itu sendiri, tetapi juga mengenai strategi yang akan ditempuh, misalnya dalam bentuk matapelajaran terpisah, berdiri sendiri [separated], atau sebaliknya "terpadu" atau terintegrasi [integrated]. "Dalam konteks teoritis, pendidikan multikulturalisme yang dikembangkan di negaranegara maju, dikenal lima pendekatan, yaitu : Pertama, pendidikan mengenai perbedaanperbedaan kebudayaan atau multikulturalisme. Kedua, pendidikan mengenai perbedaan-perbedaan kebudayaan atau pemahaman kebudayaan. Ketiga, pendidikan bagi pluralisme kebudayaan. Keempat pendidikan dwi-budaya. Kelima, pendidikan multikultural sebagai pengalaman moral manusia" [el-Ma'hady, 2004].

Terlepas dari berbagai pemikiran, pandangan, isu dan masalah yang mencuat, tanpaknya perkembangan Indonesia saat sekarang ini mendesak membutuhkan suatu desain "pendidikan multikulturalisme" yang diharapkan dapat merubah modelmodel pendidikan selama ini dan dapat memberikan kontribusi yang signifikan bagi terbentuknya "keikaan" di tengah "kebhinnekaan" yang betul-betul akurat dan aktual di tengah-tengah kehidupan masyarakat dan bangsa serta tidak hanya sekedar pada wacana, simbol, slogan, dan jargon yang selalu menggiurkan dan pembodohan masyarakat.

\section{Pendidikan Multikulturalisme di Indonesia}

Pada awal pembicaraan di atas, dikatakan bahwa kesadaran tentang multikulturalisme sudah muncul sejak negara Republik Indonesia terbentuk dan digunakan oleh pendiri bangsa Indonesia untuk mendesain kebudayaan bangsa indo 
nesia. Di Indonesia saat sekarang, tampaknya pendidikan multikultural relatif baru dikenal sebagai suatu pendekatan yang dianggap lebih sesuai bagi masyarakat Indonesia yang heterogen, multi etnis, suku, agama dan terlebih pada masa otonomi dan desentralisasi yang baru dilakukan. Pendidikan multikultural yang dikembangkan di Indonesia sejalan pengembangan demokrasi yang dijalankan sebagai counter terhadap kebijakan desentralisasi dan otonomi daerah. Apabila konsep ini dilaksanakan dengan tidak berhati-hati justru akan menjerumuskan ke dalam perpecahan nasional.

Model pendidikan multikultural di Indonesia perlu memakai kombinasi modelmodel yang telah ada. Artinya, desain model pendidikan multikultural di Indonesia tidak sekedar merevisi materi pembelajaran, tetapi perju melakukan perombakan atau reformasi secara total dalam sistem pembelajaran di sekolah-sekolah maupun di masyarakt luas untuk meningkatkan kepekaan sosial, penghargaan dan penghormatan pada budaya, nilai-nilai kemanusiaan, toleransi dan mengurangi prasangka antar kelompok. Untuk mewujudkan model-model tersebut, pendidikan multikultural di Indonesia perlu memakai kombinasi yang ada, seperti yang dikemukakan Gorski, pendidikan multikultural dapat mencakup tiga hal jenis transformasi, yakni : [1] transformasi diri, [2] transformasi sekolah dan proses belajar mengajar, dan [3] transformasi masyarakat [Gorski, dalam el-Ma'hady, 2004].

Untuk menyusun dan mendesain pendidikan multikultural dalam tatanan masyaraikat yang penuh permasalahan anatar kelompok mengandung tantangan yang tidak ringan. Pendidikan multikultural tidak berarti sebatas "merayakan keragaman" belaka, apalagi jika tatanan masya- rakat yang ada masih penuh diskriminasi dan bersifat rasis, maka dapat pula dipertanyakan apakah mungkin meminta siswa yang dalam kehidupan sehari-hari mengalami diskriminasi atau penindasan karena etnis dan suku atau perbedaannya dari budaya yang dominan tersebut? Kondisi demikian pendidikan multikultural lebih tepat diarahkan sebagai advokasi untuk menciptakan masyarakat yang toleran dan bebas toleransi yang menghargai dan menghormati perbedaan kebudayaan kelompok minoritas.

Ada beberapa pendekatan dalam proses pendidikan multikultural, yang dapat dikaji sebagai upaya perbaikan pendidikan menuju pendidikan multikulturalisme, yaitu: [1] tidak lagi terbatas pada menyamakan pandangan pendidikan [education] dengan persekolahan [schooling] atau pendidikan multikultural dengan program-program sekolah formal. Pendidikan yang lebih luas mengenai pendidikan sebagai transmisi kebudayaan yang membebaskan pendidik dari asumsi bahwa tanggung jawab primer mengembangkan kompetensi kebudayaan di kalangan peserta didik semata-mata berada di tangan mereka dan justru semakin banyak pihak yang bertanggung jawab karena program-program sekolah seharusnya terkait dengan pembelajaran informal di luar sekolah. [2] menghindari pandangan yang menyamakan kebudayaan dengan kelompok etnik adalah sama. Dalam konteks pendidikan multikultural, pendekatan ini diharapkan dapat mengilhami para penyusun program-program pendidikan multikultural untuk melenyapkan kecenderungan memandang peserta didik secara stereotip menurut identitas etnik mereka dan akan meningkatkan eksplorasi pemahaman yang lebih besar mengenai kesamaan dan perbedaan di kalangan anak didik dari berbagai kelompok etnik, [3] pengembangan 
kompetensi dalam suatu "kebudayaan baru" biasanya membutuhkan interaksi inisiatif dengan orang-orang yang sudah memiliki kompetensi, bahkan dapat dilihat lebih jelas bahwa uapaya-upaya untuk mendukung sekolah-sekolah yang terpisah secara etnik adalah antitesis terhadap tujuan pendidikan multikultural, [4] pendidikan multikultural meningkatkan kompetensi dalam beberapa kebudayaan dan kebudayaan mana yang akan diadopsi ditentukan oleh situasi, [5] kemungkinan bahwa pendidikan [sekolah maupun luar sekolah] meningkatkan kesadaran tentang kompetensi dalam beberapa kebudayaan. Kesadaran seperti ini kemudian akan menjauhkan kita dari konsep dwi budaya atau dikhotomi antara pribumi dan non-pribumi. Pendekatan ini meningkatkan kesadaran akan multikulturalisme sebagai pengalaman normal manusia. Dengan pendidikan multikultural berpotensi untuk menghindari dikotomi dan mengembangkan apresiasi yang lebih baik melalui kompetensi kebudayaan yang ada pada diri peserta didik [el-Ma'hady, 2004].

Dalam rangka mencari konsep pendidikan multikultural untuk Indonesia, menurut Tilaar, perlu memperhatikan lima tipologi pendidikan multikultural yang berkembang, yaitu: [1] Mengajar mengenai kelompok siswa yang memiliki budaya yang lain [culture difference], perubahan ini terutama pada siswa dalam transisi dari berbagai kelompok kebudayaan ke dalam mainsream budaya yang ada. [2] Hubungan manusia [human relation], program ini membantu siswa dari kelompok-kelompok tertentu sehingga dia dapat mengikuti bersama-sama dengan siswa yang lain dalam kehidupan social. [3] Single group studies, program ini mengajarkan mengenai hal-hal yang memajukan pluralisme tetapi tidak menekankan kepada adanya perbedaan stratifikasi sosial yang ada di dalam masyarakat. [4] Pendidikan multikultural, program ini merupakan suatu reformasi pendidikan di sekolah-sekolah dengan menyediakan kurikulum serta materi-materi pelajaran yang menekankan kepada adanya perbedaan siswa dalam bahasa, yang keseluruhannya untuk memajukan pluralisme kebudayaan dan ekualitas sosial. [5] Pendidikan multikultural yang sifatnya rekonstruksi social, program ini merupakan suatu program baru yang bertujuan untuk menyalurkan perbedaanperbedaan kultur dan menantang ketimpangan-ketimpangan sosial yang ada dalam masyarakat. Program yang kelima ini dapat disebut sebagai "critical multicultural education" [H.A.R. Tilaar, 2004:182].

Dapat dikatakan bahwa, pendidikan multikulturalisme merupakan pendidikan yang menyiapkan peserta didik "melek" warga negara, etnis, suku, agama, budaya, dan perbedaan yang lain, sehingga peserta didik dapat berperan secara efektif dalam interaksi sosial baik dalam lingkungan budayanya sendiri maupun di luar lingkungan budayanya. Untukmencapai tujuan pendidikan multikuluralisme, ada hal yang harus diperhatikan oleh para pendisain kurikulum dan penyelenggara pendidikan, baik pada level operasional [sekolah] maupun pada level pembuat kebijakan [Dinas Diknas], yakni: [1] integrasi isi, mengupayakan agar guru memasukkan informasi ke-etnis-an dalam pembelajaran. Seperti memberikan contoh, data, maupun informasi dari berbagai kebudayaan ras atau etnis sebagai ilustrasi dalam menjelaskan konsep-konsep kunci dari mata pelajaran yang diajarkan. [2] Proses pembentukan pengetahuan, berkenaan dengan prosedur bagaimana guru membantu siswa memahami materi pembelajaran dan bagaimana posisi individual dan kelompok etnis/ras dan kelas sosial berpengaruh terhadap upaya 
memahami materi tersebut. [3] Reduksi prasangka, pengurangan prasangka sosial dalam pendidikan multikultur berkenaan dengan karakteristik sikap rasial siswa dan strategi-strategi yang dapat digunakan untuk membantu mereka menumbuhkan sikap dan nilai-nilai yang lebih demokratis. [4] Keadilan pendidikan, berkenaan dengan upaya guru untukmemfasilitasi berbagai kelompok etnis atau kelas sosial agar mendapat kesempatan yang sama dalam perolehan pembelajaran di kelas. [5] Pemberdayaan kultur sekolah, berkenaan dengan proses merestrukturisasi kebudayaan dan organisasi sekolah agar siswa dari berbagai etnis dan kelas sosial yang beragam itu kesempatan yang sama untuk memperoleh pendidikan [Zakso, 2004]. Kategorisasi dimensi pendidikan multikulturalisme ini memang tidak mutlak exclusive dan baku, boleh jadi ada dimensi yang tumpang tindih. Namun, pengkategorisasian seperti ini - sangat dibutuhkan untuk mempermudah konseptualisasi pendidikan multikulturalisme di Indonesia.

- Apabila "inkorporasi pendidikan multikultural ke dalam program pendidikan anaǩ juga memiliki harapan dan cita-cita [Pramono, 1999:6, dalam Aisyah Amini, 2004:40]. Berikut ini adalah beberapa daripadanya, yaitu : [1] Pendidikan multi-. kultural adalah pendidikan yang menghargai pluralisme budaya. Artinya, pluralisme budaya itu tidak hanya ditoleransi tetapi dirangkul dan keragaman pengalaman manusia diharapkan memberiakan kearifan budaya. [2] Pendidikan multikultural, secara eksplisit mengakui dan menyambut keragaman dari warisan etnis yang ditemukan dalam diri setiap "orang indonesia". [3] Pendidikan multikultural tidak memaksa atau menolak anak kerana identitas suku, agama, ras, golongan. [4] Pendidikan multikultural, mengakui kebutuhan dan manfaat anak untuk berbagi bersama [sharing] diversitas warisan etnik mereka. [5] Pendidikan multikultural, mengakui pentingnya semua anak memiliki banyak kesempatan untuk berinteraksi secara positif dan personal dengan anakanak dari berbagai latar belakang sosial ekonomi dan warisan budaya, dan [6] Pendidikan multikultural, memberikan pada setiap peserta didik kesempatan untuk membantu berkembangnya sense of self. Hal ini, terutama bagi peserta didik yang secara ekonomi "kurang beruntung" atau yang berasal dari sebuah kelompok etnik yang relatif terisolasi atau yang memiliki sejarah penderitaan yang panjang akibat dari diskriminasi dan prasangka.

Dengan demikian, apabila peserta didik belajar tentang dan bangga terhadap keunikan warisan budayanya sendiri, keragaman etnis dan kelas sosial, suku, ras, agama, budaya, dan perbedaan yang lain, maka peserta didik tersebut akan terbantu dalam menjawab pertanyaan "siapakah saya" ? dan "siapakah orang Indonesia"? Pertanyaan ini merupakan sangat mendasar dari seorang peserta didik yang memiliki budaya sendiri dan kemungkinan besar pertanyaan yang sama ini juga akan dijawab oleh peserta didik yang telah melakukan sharing dengan peserta didik yang lain dengan latar belakang etris, kelas sosial, suku, ras, agama dan budaya yang lain. Apakah peserta didik tersebut mengembangkan identitas etnisnya yang kuat ataukah tidak, yang pasti mereka semua pada waktu bersamaan mempelajari kekayaan multikultural dari identitas mereka sendiri dan identitas etnis lain yang akan menumbuhkan "rasa keindonesiaan".

Dari kesemua pemikiran dan pandangan yang dikemukakan di atas, Tilaar [2004:187-190], mencoba mengelaborasi 
dengan menyusun konsep pendidikan multikultural yang sekiranya dapat dikembangkan di tanah air kita yang sesuai dengan kondisi sosial, budaya, dan politik di Indonesia. Menurutnya, pendidikan multikultural mempunyai dimensi sebagai berikut.

Pertama, Konsep pendidikan multikultural normatif, kita tidak dapat menerima konsep pendidikan multikultural yang deskriptif yaitu hanya sekedar mengakui adanya pluralitas budaya dari suku-suku bangsa di Indonesia. Menurutnya, konsep pendidikan mutikultural normatif adalah konsep yang dapat digunakan untuk mewujudkan cita-cita tersebut. Pendidikan multikultural normatif justru merupakan identitas suatu suku yang kemudian dapat menyumbangkan bagi terwujudnya suatu kebudayaan Indonesia yang dimiliki oleh: seluruh bangsa Indonesia. Konsep ini, tidak dapat dipaksakan melalui program-program hafalan atau praksis pendidikan yang menekankan kepada simbol-simbol kesatuan bangsa, tetapi dalam praktiknya kita menghancurkan citra dari suatu bangsa yang pluralistik.

Kedua, pendidikan multikultural merupakan suatu rekonstruksi sosial. Suatu rekonstruksi sosial artinya upaya untuk melihat kembali kehicupan sosial yang ada dewasa ini. Jadi, pendidikan multikultural tidak ada pengelompokan-pengelompokan komunitas yang mengagungkan nilai-nilai kelompoksendiri tetapi yang mengenal akan nilai-nilaj hidup budaya suku/komunitas yang lain. Menurutnya pendidikan multikultural tidak akan dikenal adanya fanatisme atau fundamentalisme sosialbudaya, karena masing-masing komunitas mengenal dan menghargai perbedaanperbedaan yang ada. Pendidikan multikultural bertugas untuk memperdalam akan rasa identitas kesukuan yang kemudian secara terbuka mengenal dan mengerti akan nilai-nilai sosial-budaya dan agama dari. suku-suku yang lain.

Ketiga, pendidikan multikultural bertujuan untuk mewujudkan visi Indonesia masa depan serta etika berbangsa. Pada TAP/MPR RI Tahun 2001 No. VI dan VII mengenai visi Indonesia masa depan serta etika kehidupan berbangsa perlu djjadikan pedoman yang sangat berharga dalam pengembangan konsep pendidikan multikultural. Dalam kaitan ini perlu dipertimbangkan untuk menghidupkan kembali pendidikan budi pekerti terutama di tingkat pendidikan dasar dan melengkapi pendidikan agama yang yang telah diatur dalam UU No. 20 Tahun 2003.

Keempat, pendidikan multikultural di Indonesia memerlukan pedagogik baru. Untuk melaksanakan konsep pendidikan multikultural di dalam masyarakat pluralistik tapi sekaligus diarahkan kepada terwujudnya masyarakat Indonesia baru, maka pedagogik yang tradisional tidak dapat digunakan lagi. Sebab pedagogik tradisional membatsi proses pendidikan di dalam ruang kelas di sekolah yang sarat dengan pendidikan intelektualistik. Sementara kehidupan sosial-budaya di Indonesia menuntut pendidikan hati [pedagogy of hearf] yaitu diuarahkan kepada rasa persatuan dari bangsa Indonesia yang pluralistik, maka model pedagogik baru yang dibutuhkan ialah. : [1] Pedagogik pemberdayaan [pedagogy of empowement]. [2] Pedagogik kesetaraan sesama manusia dalam kebudayaan yang beragam [pedagogy of equity]. Pedagogik pemberdayaan, berarti seseorang mengenal akan budaya sendiri dan kemudian keberdayaan itu digunakan untuk mengembangkan budaya Indonesia di dalam negara-bangsa Indonesia. Dalam upaya tersebut diperlukan suatu pedagogik kesetaraan antara individu, antar suku, dan 
tidak membedakan asal-usul suku dan agamanya. Tetapi kedua jenis pedagogik tersebut, memerlukan suatu pendekatan terhadap proses pendidikan, yaitu keikutsertaan semua komponen atau stakeholder pendidikan.

Dari pandangan keempat di atas, program pembelajaran multikultural yang akan dikembangkan berdasarkan pada konsep pluralisme budaya, sehingga program pendidikan menyediakan lingkungan belajar ganda kepada peserta didik [ multiple leaming environments] yang memiliki kesesuai dengan kebutuhan dasar akademik dan sosial peserta didik. Model pembelajaran multikultural yang dikembangkan diarahkan pada pencapajan kompetensi-kompetensi standar dan dasar [standard and basic academic skill] tentang nilai-nilai persatuan dan kesatuan, kemanusiaan, demokratis, keadilan, kebebasan, persamaan derajat atau saling menghormati dan menghargai dalam keragaman budaya. Mengembangkan kompetensi sosial agar dapat menumbuhkan pemahaman tantang latar belakang budaya sendiri dan budaya lain dalam masyarakat. Mengembangkan kompetensi akademik untuk menganalisis dan membuat keputusan yang bijak dan cerdas tentang isu-isu dan masalah keseharian melalui sebuah proses demokratis atau inkuiri dialogis. Membantu mengkonseptualisasikan dan mengaspirasikan sebuah masyarakat yang lebih baik, demokratis [Aisyah Amini,2004:47], taat hukum dan menghargai hak asasi manusia, toleran, terbuka dan memiliki persamaan derajat.

Apabila bangsa ini ingin menjadi kuat dalam era reformasi dan demokrasi, diperlukan sikap saling menghargai dan menerima dari setiap orang dan kelompok yang beraneka ragam budaya dan adatistiadat, sehingga dapat saling membantu dan bekerja sama untuk membangun negara ini yang lebih baik. Sifat sukarela, sadar dan penuh keterbukaan untuk hidup berdampingan dalam format negara kesatuan republik Indonesia dapat dikembangkan melalui pendidikan dengan komsep pendidikan multikulturalisme yaitu suatu konsep pendidikan yang mengedepankan semangat persatuan "Bhineka Tunggal lka", solidaritas sosial, prinsip keadilan, kesederajatan, kebebasan mengembangkan diri, peluang dan kesempatan yang sama dalam berprestasi individu.

\section{Budaya Bangsa dan Pendidikan Multikulralisme}

Konsep dari "founding fathers" kita yang mengatakan kebudayaan nasional sebagai puncak-puncak kebudayaan sukusuku yang ada di Nusantara ini dapat dikaji secara terus-menerus dalam rangka membina apa yang disebut kebudayaan indonesia yang akan merupakan landasan yang kuat bagi Sistem Pendidikan Nasional. Dari sini, perlu dikembangkan konsep pendidikan multikulturalisme di Indonesia yang sesuai dengan kondisi sosial-budaya dan geografi negara-bangsa Indonesia dengan mencari format yang tepat dalam mengawinkan paham neoliberalisme pendidikan dengan multikulturalisme [Tlaar, 2004:184].

Keragaman etnis, suku, agama dan budaya atau kebhinnekaan atau multikultural merupakan salah satu realitas utama yang dialami masyarakat dan kebudayaan Indonesia pada awal negera ini didirikan oleh "founding fathers" pada masa silam dan lebih-lebih lagi pada masa kini dan di waktu mendatang. Menurut Azra, yang penting dicatat, bahwa keragaman itu hendakiah tidak diinterpretasikan "secara tunggal". Oleh karena, komitmen untuk mengakui 
"keragaman" yang terhubungkan dalam "budaya bangsa", "merupakan salah satu ciri dan karakter utama masyarakat-masyarakat dan negara-bangsa, seperti Indonesia, tetapi hal ini tidaklah berarti ketercerabutan, relativisme kultural, disrupsi sosial, atau konflik berkepanjangan pada setiap komunitas, masyarakat dan kelompok etnis dan rasial, bukan akibat dari "keragaman" tersebut. Sebab, Azra, mengatakan bahwa pada saat yang sama juga sesungguhnya terdapat simbol-simbo!, nilai-nilai, strukturstruktur dan lembaga-lembaga dalam kehidupan bersama yang mengikat berbagai keragaman tadi....Dengan kata lain, mereka menekankan pada kehidupan bersama, saling mendukung dan menghormati satu sama lain dalam berbagai hak dan kewajiban personal maupun komunal, dan lebih jauh lagi masyarakat nasional. Komitmen terhadap nilai-nilai tidak dapat dipandang berkaitan hanya dengan eksklusivisme personal dan sosial saja, atau dengan superioritas kultural, tetapi lebih jauh lagi dengan kemanusiaan [humanness], komitmen dan kohesi kemanusiaan termasuk di dalamnya melalui toleransi, saling menghormati hak-hak personal dan komunal. Manusia, ketika berhadapan dengan simbol-simbol, doktrin-doktrin, prinsip-prinsip dan pola-pola tingkah laku, sesungguhnya mengungkapkan dan sekaligus mengidealisasikan komitmen kepada kemanusiaan-baik secara personal maupun komunal—dan kebudayaan yang dihasilkannya [Azra, akses,24/5/2005].

Tilaar menyatakan, bahwa lahirnya identitas kesukuan sebagai perkembangan budaya mikro di Indonesia, memang memerlukan masa transisi yaitu seakanakan melorotnya rasa kebangsaan dan persatuan Indonesia sebagái budaya mainstream belum jelas bagi kita semua. Menurutnya, apakah yang dimaksud dengan kebudayaan Indonesia? Apakah yang dimaksud dengan puncak-puncak kebudayaan suku bangsa yang ada di Nusantara ini? Semua hal tersebut memang diakui belum kita miliki. Identitas budaya makro, yaitu budaya Indonesia yang -sedang menjadi memang harus terus menerus dibangun atau merupakan suatu proses tanpa ujung [Tilaar 2004:186]. Artinya, pendidikan multikultural di Indonesia diarahkan kepada terwujudnya budaya bangsa menuju masyarakat madani Indonesia di tengah-tengah kekuatan kebudayaan global.

Realitas Indonesia yang "multi-kultural" ini tentu berhadapan dengan berbagai masalah dalam masa reformasi sekarang ini, maka terlihat adanya kebutuhan mendesak untuk merekontruksi kembali "kebudayaan nasional Indonesia" yang dapat menjadi "integrating force" yang mengikat seluruh keragaman etnis dan budaya tersebut. Pembentukan masyarakat multikultural Indonesia yang demokratis tidak bisa secara taken for granted atau trial and error. Harus diupayakan secara sistematis, programatis, integrated dan berkesinambungan dan salah satu langkah yang paling strategis dalam hal ini adalah melalui pendidikan multi-kultural yang diselenggarakan melalui seluruh lembaga pendidikan, baik formal maupun non-formal, dan bahkan informal dalam masyarakat luas [Azra, akses,24/5/2005].

Dari pandangan ini, pendidikan merupakan proses budaya untuk meningkatkan harkat dan martabat manusia yang berlangsung sepanjang hayat. Upaya pendidikan yang dilakukan oleh suatu bangsa memiliki hubungan yang signifikan dengan rekayasa bangsa tersebut di masa mendatang. Sebagai contoh saja, pada masyarakat agraris pendidikan didisain agar relevan dengan kebutuhan dan mengikuti 
perkembangan masyarakat pada era tersebut, begitu juga perubahan peradaban masyarakat yang menjadi masyarakat industrial dan informasi pendidikan juga didisain mengikuti irama perkembangan masyarakat industri dan informasi, dan seterusnya, demikian siklus perkembangan[Sanaky, 2002:209] dan kita sekarang dihadapatkan pada era reformasi, globalisasi, dan berbagai konflik kepanjangan yang terjadi. Peran pendidikan multikultural menumbuhkan pemahaman lebih benar tentang keragaman budaya, etnis dan agama, demokratisetuk, HAM, pluralitas, toleransi di antara berbagai komunitas menjadi "budaya bangsa Indonesia" merupakan suatu yang urgen. Atau, "barangkali, kita periu belajar dari kesalahan masa lalu yang terlalu menekankan kepada "nation building" dan mematikan capital budaya bangsa [cuitural capital] yang pada masing-masing suku bangsa kita merupakan kekuatan budaya nasional apabila dipupuk dan ciarahkan secara posetif. Demikian pula kita belajar dari kesalahan Orde Baru, di mana kesatuan dan persatuan nasional merupakan hal-hal hafalan belaka melalui program P-4 dan tidak dilaksanakan dalam kehidupan sehari-hari [Tllaar, 2004:184] oleh semua lapisan masyarakat dan bangsa Indonesia.

Tolstoy berpendapat sasaran puncak pendidikan ada di lụar pendidikan [Achambault, dalam Freire, 2001:491], yaitu "kebudayaan". Tolstoy beranggapan nilainilai masyarakat "beradab" akan tetap bertahan meski dihujani aneka ragam konflik atau ajang klaim-klaim yang saling bertentangan. Usaha peradaban bangsa Indonesia sejak dulu telah dimulai dari pendidikan, seperti dilakukan ke tiga tokoh pendiri pendidikan, yaitu dengan memakai bahasa Melayu sebagai bahasa pengantar pendidikan, yang kemudian menjadi bahasa
Indonesia dan bahasa Indonesia menjadi bahasa persatuan. Ini suatu peradaban tinggi yang tidak dimiliki bangsa lain. Tampaknya, melalui pendidikan peradaban bangsa dapat dibentuk, jika pendidikan dapat dianggap sebagai wujud dari reformasi budaya bangsa, wujud-wujud itu adalah bagaimana cara kita menanam nilai-nilai budaya etnik daerah di kelas tanpa ada pergesekan antar etnik.

Dari pandangan yang dikemukakan di atas, maka acuan utama bagi terwujudnya masyarakat dan "budaya bangsa" Indonesia yang multikultural adalah multikulturalisme, yaitu sebuah ideologi yang mengakui dan mengagungkan perbedaan dalam kesederajatan baiksecara individual maupun secara kebudayaan [Fay 1996, Jary dan Jary 1991, Watson 2000]. Dalam model multikulturalisme ini, sebuah masyarakat [termasuk juga masyarakat bangsa seperti Indonesia] dilihat sebagai mempunyai sebuah kebudayaan yang berlaku umum dalam masyarakat tersebut yang coraknya seperti sebuah "mosaic". Di dalam mosaik tercakup semua kebudayaan dari masyarakat-masyarakat yang lebih kecil yang membentuk terwujudnya masyarakat yang lebih besar, yang mempunyai kebudayaan yang seperti sebuah mosaik tersebut [Reed, ed. 1997] [Parsudi Suparlan, akses, 23/5/2005]. Model multikulturalisme ini sebenarnya telah digunakan sebagai acuan oleh para pendiri [founding fathers] bangsa Indonesia dalam mendesain apa yang dinamakan sebagai kebudayaan bangsa, sebagaimana yang terungkap dalam penjelasan Pasal 32 UUD 1945, yang berbunyi: "kebudayaan bangsa [Indonesia] adalah puncak-puncak kebudayaan di daerah". Sehingga, corak masyarakat Indonesia yang bhinneka tunggal ika bukan lagi keanekaragaman suku bangsa dan budaya, tetap merupakan keanekaragamaan budaya 
bangsa dalam masyarakat Indonesia. Kemudian dari itu semua, Tilaar, mengatakan bahwa perlu ada "kebudayaan indonesia-yang menjadi", adalah suatu weltanschauung artinya merupakan pegangan dari setiap insan dan setiap identitas "budaya mikro" Indonesia.Sebagai suatu weltanschauung, hal tersebut merupakan suatu sistem nilai yang baru [value system]. Sebagai suatu value system yang baru memerlukan suatu proses perwujudan antara lain melalui proses pendidikan nasional. Oleh sebab itu, ditengah-tengah maraknya identitas kesukuan, perlu ditekankan sistem nilai baru yang akan kita wujudkan, yaitu sistem nilai keindonesiaan [Tilaar, 2004:186].

Kata akhir, tulisan ini hanya sebagai suatu kajian awal untuk menunjukkan upaya membangun Indonesia multikultural dan pendidikan multikulturalisme hanya mungkin dapat terwujud, apabila konsep multikulturalisme menyebar luas dan dapat dipahami bahwa konsep ini pentingn bagi bangsa Indonesia dan adanya keinginan serta upaya bangsa Indonesia pada tingkat nasional maupun lokal untuk dapat mengadopsi dan menjadi pedoman hidup dalam bermasyarakat dan bernegara. Maka diperlukan upaya-upaya yang dapat dilakukan untuk dapat mewujudkan cita-cita ini. Selain itu, diperlukan juga kesamaan pemahaman diantara para ahli mengenai makna dan bangunan konsep-konsep multikulturalisme yang mendukungnya.

\section{Penutup}

Terlepas dari berbagai pemikiran, pendapat, isu dan masalah yang mencuat, tanpaknya perkembangan Indonesia saat sekarang ini dan mendesak membutuhkan suatu desain "pendidikan multikulturalisme" yang diharapkan dapat merubah model- model pendidikan selama ini dan dapat memberikan kontribusi yang signifikan bagi terbentukannya "keikaan" dj tengah "kebhinnekaan" yang betul-betul akurat dan aktual ditengah-tengah kehidupan masyarakat dan bangsa serta tidak hanya sekedar pada wacana, simbol, slogan dan jargon yang selalu menggiurkan atau pembodohan masyarakat.

Pendidikan multikultural merupakan suatu pendekatan progresif untuk melakukan transformasi pendidikan yang secara menyeluruh dan membongkar kekurangan dan kegagalan serta praktikpraktik diskriminasi dalam proses pendidikan selama ini. Konsep pendidikan multikultural harus didasarkan pada gagasan keadilan sosial, demokratis, keterbukaan, persamaan hak, kesederajatan, menghormati dan menghagai perbedaan etnis, suku, agama dan budaya dalam proses pendidikan.

Pendidikan multiku|tural seyogyanya memfasilitasi proses belajar mengajaryang mengubah "perspektif monokultural" yang esensial, penuh prasangka dan diskriminatif ke "perspektif multikulturalis" yang menghargai keragaman, perbedaan, toleran dan sikap terbukaan. Dengan demikian, tidak saatnya lagi pendidikan mengabaikan realitas kebudayaan yang beragam tersebut.

\section{Daftar Pustaka}

Aisyah Amini, Ernie Isis, 2004, Analisis Kebutuhan Pendidikan Multikultural Berbasis Kompetensi Pada Siswa Sekolah Lanjutan Tingkat Pertama [SLTP] di Kota Mataram, Program Pascasarjana IKIP Negeri Singaraja, Mataram.

Atmadja, Nengah Bawa, 2003, Multikulturalisme dalam Perspektif 
Filsafat Hindu, Makalah di Sajikan dalam Seminar Damai Dalam Perbedaan, Singaraja, 5 Maret 2003.

Azra, Azyumardi, 2002, Pendidikan Multikultural: Membangun Kembali Indonesia Bhineka Tunggal lka, Makalah disampaikan dalam Symposium Internasional Antropologi Indonesia ke-3, Denpasar, Kajian Budaya UNUD.

, Identitas dan Krisis Budaya, Membangun Multikulturalisme Indonesia, From:http://kongres.budpar.go.id/ agenda/precongress/makalah/ a b s t r a k/ $58 \% 20$ azyumardi\%20azra.htm, akses, Selasa, 24 maei 2005, jam. 11.00

el-Ma'hady, Muhaemin, 2004, Multikulturalisme dan Pendidikan Multikultural [Sebuah Kajian Awal], From: http://artikel.us/muhaemin6-04.html, senin, 23 maei 2005, jam. 16.00

Freire, Paulo, Pendidikan pembebasan, Jakarta, LP3S, 2000 IKA UIN Syarif Hidayatullah, Majalah: Tsaqafah: Mengagas Pendidikan Multikultural, Vol. I No:2, 2003.

Freire, P. 2001. Menggugat Pendidikan, Yogyakarta: Pustaka Pelajar.

Hasan, Hamid, 2002, Pendekatan Multikultural Untuk Penyempumaan Kurikulum Nasional. Dalam Seminar Pengembangan Kurikulum Universitas Pendidikan Indonesia [UPI], Bandung.

Pramono, Suwito Eko, 1999, Urgensi Pendidikan Multikultural dalam
Pendidikan IPS, Seminar :dan Sarasehan Forum Komunikasi IX, Pimpinan FPIPS-IKIP dan JPIPSFKIP/STKIP Se Indonesia, STKIP Singaraja, Bali.

Puwasito, Andrik, 2003, Komunikasi Multikultural, Surakarta, Muhammadiyah University Press.

Sanaky, Hujair AH., 2002, Pembaruan Pendidikan Islam Menuju Masyarakat Madani Indonesia Tinjauan Sosiokultural Historis], Tesis S-2, Magister Studi Islam, Yogyakarta.

Semiawan, Conny, 2002, Belajar dan Pembelajaran Dalam Taraf Usia Dini, Jakarta, PT. Prenhallindo.

Sparadley, James, P., 1997, Metode Etnografi, terj. Misbah Zulfa Elizabeth, Yogyakarta, Tiara Wacana.

Sudiro, M. Irsyad, Pendidikan Agama dalam Mansyarakat Modern, Seminar dan Lokakarya Nasional Revitalisasi Pendidikan Agama Luar Sekolah Dalam Masyarakat Modern, Cirebon,Tgl. 30-31 Agustus 1995.

Suparlan, Parsudi, 2002, Menuju Masyarakat indonesia Yang Multikultural, Makalah, Disajikan pada Simposium Internasional Jumal Antropologi Indonesia ke-3, Membangun Kembali "Indonesia yang Bhinneka Tunggal lka", Menuju Masyarakat Multikultural, Universitas Udayana, Denpasar, Bali, 16-19 Juli 2002, From: http:// www.scripps.ohiou.edu/news/cmdd/ artikel ps.htm, Akses, Senin, 23 mei 2005, jam 16.00]. 
Topik: Agama dan Teologi Populis Transformatif

Tilaar, H. A. R, 2002, Perubahan Sosial dan Pendidikan: Pengantar Pedagogik Transformatif untuk Indonesia, Jakarta, Grasindo, ,2004, Multikulturalisme Tantangan-tantangan Global Masa Depan dalam Transformasi Pendidikan Nasional, Jakarta, Grasindo.
Zakso, Amrazi, 2004, Menggagas Pendidikan Multikultural di Kalimantan Barat, From: http:// www.pontianakpost.com/berita/ index.asp?Berita=Edukasi\&id=71626, selasa, 24 mei 2005, jam 11.00. 